\title{
DYNAMIC OF GIRL STUDENTS' PSYCHO-PHYSIOLOGICAL INDICATORS IN PROCESS OF THEIR STUDY AT PEDAGOGICAL HIGHER EDUCATIONAL ESTABLISHMENT
}

Kolumbet A.N.

Kiev National University of Technology and Design

\begin{abstract}
Purpose: to study dynamic of psycho-physiological indicators of pedagogic higher educational establishments' girl students. Material: in the research 510 girl students participated. We assessed: responsive abilities, static and dynamic balance, orientation in space, quickness of operational thinking, volume of rote memorization, distribution of attention, accuracy level, quickness and re-switching of attention, accuracy of fulfillment of task. Results: we have found weakening of accuracy of movement's amplitude and pre-set value of force reproduction; reduction of indicators of response to vertically falling object, static and dynamic balance. We also registered improvement of indicators of nervous processes' dynamic and ability to constructive praxis. Conclusions: uneven reduction of most of psycho-physiological indicators negatively reflects in girl students' motor fitness level and professional abilities.
\end{abstract}

Key words: psycho-physiological, girl students, professional, abilities, pedagogic.

\section{Introduction}

Working time of teachers is 3-5 working hours directly on working place and 2-4 hours of independent work at home. Such working mode causes deficit of motor functioning, which is called hypokinesia [15]. It is manifested in work with limited movements, low energy consumption by muscles, local muscular functioning, keeping forced working position for long period of time, monotonous movements, high nervous emotional background [15, 18, and 21].

Keeping forced working position for long period of time is very unfavorable factor of teachers' professional functioning. As a rule, teachers (mainly of older generation) shall keep very monotonous position (sitting or standing) in process of their professional functioning. It makes background and chest the less mobile parts of body and results in loss of backbone's flexibility and correct correlation of muscles [18, 30]. Besides, teachers have to make many local movements by muscles of forearm and hand during working day. Some researchers confirm that great load on weal muscles can cause over-fatigue of these muscular groups. In its turn it results in increased attention to nervous-muscular apparatus of both arms [17, 26, 33, and 34]. These teachers often suffer from bad eyesight, fatigue of arms and backbone muscles [22, 24].

At present, girl students of pedagogic specialties have spend much time working with computer. It is characterized by immobile static posture, minimal monotonous movements of upper limbs, constant tension of eyesight. All these factors negatively influence on their self feeling [35]. Part of pedagogic work implies being in vertical position with static load on legs' muscles. High academic load against the background of low motor functioning and long keeping of static posture is one of factors, inhibiting physical development and psychophysiological status of organism $[2,28]$. Restriction of motor functioning negatively influences on human health $[36,39]$.

In many works $[2,6,10,11,27$, and 31$]$ attention is paid to possible deviations in health, weakening of general physical and mental workability, initial disorders in some functional systems of organism. In particular, K.A. Sidorova [23] et al. researched temper, quickness of response of urban and countryside girl students. In researches by O.G.Litovchenko [19] the data of simple and complex visual motor responses and operational memory were analyzed. A.V. Kostiunin [16] studied functional mobility of nervous processes, reaction to moving object. Thus, researchers rather widely analyze different psycho-physiological indicators of students in dynamic. Only in works by L.N. Barybina [3] there is a conclusion about interconnection of psycho-physiological indicators with individualization of physical education at higher educational establishment. With it, researchers have not analyzed influence of psycho-physiological indicators' dynamic on professional qualities of future profession. As a result there is a question about purposefulness of specialized physical education for improvement of these indicators.

(c) Kolumbet A.N., 2015

doi:10.15561/20755279.2015.0604 


\section{Purpose, tasks of the work, material and methods}

The purpose of the work is to study dynamic of psycho-physiological indicators of pedagogic higher educational establishments' $1^{\text {st }}-3^{\text {rd }}$ year girl students.

The methods and organization of the research: 54o girl students from 18 to 22 years' age were tested. In the research analyzer of motor-coordination reactions ADKR-2 was used.

The level of girl students' accuracy was assessed with the following tests: 1) accuracy of reproduction of pre-set value of force was determined with the help of hand dynamometer; 2) accuracy of reproduction of pre-set amplitude of arms' movements was measured with kinematic meter of M.I. Zhukovskiy.

Responsive qualities were assessed with the following tests: 1) test for quickness ("Catching of rule") [8]); 2) determination of reaction to moving object. For this test computer program "Prognoz" was used (Institute of physiology, named after A.A. Bogmolets, AS of Ukraine, Kiyev; 3) test for quickness of visual-motor response (simple and complex) (with computer program "Prognoz"); 4) test for quickness of reaction ("Catching of stick" ) [1]); 5) complex coordination test: determination of accurate, differently directed speed-power movements for definite time (computer program "Prognoz"). Для оценивания способности ориентации в пространстве использовался тест «Лабиринт» [7].

For assessment of professionally significant abilities of girl students we used the following tests:1) distribution of attention ("finding of numbers" [5]); 2) volume of rote memorization ("Quantity of men figures" [5]); 3) distribution of attention and quickness of operational thinking ("Assembly of puzzles during certain period of time" [1]); 4) quickness of operational thinking ("Koss's cubes" [5]); 5) on special device we determined: quickness, re-switching and concentration of attention; accuracy of fulfillment of pre-set task [9].

Static balance was tested with Romberg's test (posture of "Stork"); 2) dynamic balance was assessed with test "Turns on gymnastic bench" [29].

\section{Results of the research}

When testing accuracy of reproduction of pre-set space amplitude of arms' movements we analyzed dynamic of this indicator's changes without girl students' visual control. It was found that indicators of reproduction of arm movement amplitude's accuracy were the best in $1^{\text {st }}$ and $3^{\text {rd }}$ year girl students and the worst in $3^{\text {rd }}$ year girl students (see table 1). When approaching to $3^{\text {rd }}$ year of study value of error increases. Reduction of the tested indicator was $14.6 \%$. It witnesses about worsening of this indicator in the process of studying.

When testing indicator of accuracy of pre-set force value reproduction (error) we found increase from $1^{\text {st }}$ to $3^{\text {rd }}$ year of studying. It witnesses about increase of error and worsening of indicator with approaching to $3^{\text {rd }}$ year by $13.5 \%$. The worst result of this indicator was registered in $3^{\text {rd }}$ year girl students. Deviations from pre-set value of effort were nearly $3 \mathrm{~kg}$. The best indicator was in $1^{\text {st }}$ year girl students. Them steady negative dynamic appears in ability to accurately reproduce the pre-set value of force.

Analysis of results of test for quickness of reaction showed that this indicator was the highest in $1^{\text {st }}$ year girl students and the worst - in $3^{\text {rd }}$ year girl students. Dynamic of its changes is also steadily negative from $1^{\text {st }}$ to $3^{\text {rd }}$ year of study. The level of $3^{\text {rd }}$ year girl students was "below average" in comparison with mean age standards. It says about worsening of girl students' sensor motor response by the end of study period.

The same dynamic was intrinsic to indicators of second test: quickness of response to vertically falling object ("Catching of rule"). This test permitted to register the best results in $2^{\text {nd }}$ year girl students and the worst in $3^{\text {rd }}$ year girl students. Dynamic of this indicator's changes is also steadily negative from $2^{\text {nd }}$ to $3^{\text {rd }}$ year of study $(18 \%)$. It also shows worsening of motor response by the end of study. 
Table 1. Mean values of girl students' psycho-physical indicator for the period of study at higher pedagogical educational establishment

\begin{tabular}{|c|c|c|c|c|}
\hline \multirow[t]{2}{*}{ Indicator } & \multirow{2}{*}{$\begin{array}{ll}\text { Unit } & \text { of } \\
\text { measurement }\end{array}$} & \multicolumn{3}{|c|}{ Years of study } \\
\hline & & 1st & 2nd & 3rd \\
\hline $\begin{array}{l}\text { Accuracy of movements } \\
\text { amplitude's reproduction }\end{array}$ & Error, degrees & 3.34 & 3,50 & 4.70 \\
\hline $\begin{array}{l}\text { Accuracy of pre-set force value's } \\
\text { reproduction }\end{array}$ & $\mathrm{kg}$ & 2.00 & 2.40 & 2.70 \\
\hline $\begin{array}{l}\text { Quickness of response ("Catching } \\
\text { of stick" test) }\end{array}$ & time, m.sec. & 235 & 260 & 267 \\
\hline $\begin{array}{l}\text { Quickness of reaction ("Catching of } \\
\text { rule" test) }\end{array}$ & $\mathrm{cm}$ & 14.60 & 14.20 & 17.20 \\
\hline $\begin{array}{l}\text { Accuracy of response to moving } \\
\text { object }\end{array}$ & Quantity of times & 2.00 & 2.60 & 2.70 \\
\hline Forward reaction to moving object & Quantity of times & 9.70 & 7.00 & 8.10 \\
\hline Delayed reaction to moving object & Quantity of times & 8.30 & 10.40 & 9.60 \\
\hline $\begin{array}{l}\text { Quickness of simple visual-motor } \\
\text { reaction }\end{array}$ & time, m.sec. & 220 & 250 & 286 \\
\hline $\begin{array}{l}\text { Quickness of complex visual-motor } \\
\text { reaction }\end{array}$ & time, m.sec. & 479 & 429 & 410 \\
\hline $\begin{array}{l}\text { Total time of complex visual-motor } \\
\text { response }\end{array}$ & time, m.sec. & 465 & 447 & 444 \\
\hline Static balance & time, sec. & 19.40 & 15.60 & 12.10 \\
\hline Dynamic balance & time, sec. & 12.89 & 9.99 & 8.97 \\
\hline Orientation in small space & time, sec. & 10.00 & 11.75 & 11.85 \\
\hline Accuracy of orientation in space & $\mathrm{mm}$ & 1.40 & 1.70 & 1.50 \\
\hline $\begin{array}{l}\text { Orientation, responding and } \\
\text { differentiation qualities }\end{array}$ & points & 5.80 & 6.40 & 4.00 \\
\hline Quickness of operational thinking & points & 43,70 & 47.70 & 51.10 \\
\hline Distribution of attention & Conv. Un. & 37.80 & 40.40 & 35.00 \\
\hline Volume of rote memorizing & quantity & 6.20 & 5.10 & 2.90 \\
\hline $\begin{array}{l}\text { Distribution of attention and } \\
\text { quickness of operational thinking }\end{array}$ & minutes & 11.18 & 13.83 & 17.12 \\
\hline $\begin{array}{l}\text { Quickness of re-switching and } \\
\text { concentration of attention }\end{array}$ & $\begin{array}{l}\text { Quantity } \\
\text { mistakes }\end{array}$ & 0.71 & 0.80 & 0.82 \\
\hline
\end{tabular}

Analysis of changes of response accuracy to moving object indicators showed that the best results were at $3^{\text {rd }}$ year of study, the worst - at $1^{\text {st }}$ year. It should be noted that definitions "the best" and "the worst" are rather conventional.

As a result of the research we found that the highest value of forward responses' indicator was just in $1^{\text {st }}$ year girl students: from 20 offered reactions, girl students demonstrated in average 9 forward reactions. The lowest indicators were found in $2^{\text {nd }}$ year girl students. \#rd year girl students showed in average 8 forward reactions from 20 offered. Reduction of indicator from $1^{\text {st }}$ to $3^{\text {rd }}$ year was $14.4 \%$.

Quantity of delayed reactions is rather high in comparison with their total quantity for all years. It is negative indicator for characteristic of one of the most important coordination qualities of future pedagogues - to see an object in space and in movement. The main indicator of response to moving object is timeliness and quickness of response, connected with concentration of attention.

Change of indicator of simple visual-motor response (SVMR) also has negative dynamic. The best indicators of simple visual-motor response were found in $1^{\text {st }}$ year girl students and the worst - in $3^{\text {rd }}$ year girl 
students. Dynamic of the tested indicator witnesses, that from $1^{\text {st }}$ year to $3^{\text {rd }}$ year it reduced by $23 \%$. It witnesses about increasing of simple visual motor response time by the end of study period and, consequently, bout worsening of indicators of girl students' sensor motor responding by the end of study period.

Results of assessment of complex visual motor response (CVMR) witness about improvement of this quality from $1^{\text {st }}$ to $3^{\text {rd }}$ year. Analysis of this test results showed that that the best results were in $3^{\text {rd }}$ year girl students and the worst - in $1^{\text {st }}$ year girl students. Analysis of this indicator changes showed positive dynamic from $1^{\text {st }}$ to $3^{\text {rd }}$ year. Total improvement of this indicator was $13.4 \%$.

Time changes of girl students' CVMR reflected in total time of CVMR: the best indicator of total time was registered in $3^{\text {rd }}$ year girl students and the worst - in $1^{\text {st }}$ year girl students. Dynamic of this indicator's change from $1^{\text {st }}$ to $3^{\text {rd }}$ year shows that total time of girl students' CVMR shortens (up to $4.5 \%$ by the end of study period).

It was also found that from $1^{\text {st }}$ to $3^{\text {rd }}$ year there takes place negative dynamic of Romberg's test indicator ("Stork" posture). It shows worsening of girl students' ability to keep balance. Reduction of this indicator from $1^{\text {st }}$ to $3^{\text {rd }}$ year is rather substantial $-37.6 \%$. It is rather negative factor. It should be noted that in general the level of this test's results meets average age standard and is, even, at its top.

The researches also determined that from $1^{\text {st }}$ to $3^{\text {rd }}$ year there is observed steady negative dynamic of girl students' dynamic balance indicators. Reduction of these indicators was $33.5 \%$. It is also a negative factor. However, it should be noted that in general the level of this test's results meets average age standard.

Determination of accurate orientation in small space (orientation ability), considering time and accuracy showed that the best results of passing labyrinth were demonstrated by $1^{\text {st }}$ year girl students and the worst - by $3^{\text {rd }}$ year girl students. Dynamic of this indicator's changes shows that time of passing of labyrinth increases. In general by the $3^{\text {rd }}$ year time indicator worsens by $16 \%$.

Analysis of dynamic of orientation in space accuracy witnesses, that during study period there are no significant changes in ability to accurately fulfill motor actions. We found that the best indicators of this test were in $1^{\text {st }}$ year girl students and the worst - in $2^{\text {nd }}$ year girl students. Dynamic of this indicator demonstrates insignificant increase from $1^{\text {st }}$ to $3^{\text {rd }}$ year by $7 \%$.

Changes of indicators in test orientation qualities showed that the lowest values of these indicators were in $2^{\text {nd }}$ year girl students. In $3^{\text {rd }}$ year girl students we registered stabilization of these indicators. But, in general, in the process of study these indicators have negative dynamic. Complex assessment of orientation in space shows that this ability weakens by $26 \%$ by $3^{\text {rd }}$ year of study, comparing with $1^{\text {st }}$ year.

Dynamic of complex coordination test results (assessment of orientation, responding and differentiation qualities) showed that the best results were received in $2^{\text {nd }}$ year girl students and the worst $-3^{\text {rd }}$ year girl students. In general reduction of this indicator from $2^{\text {nd }}$ to $3^{\text {rd }}$ year was $13.4 \%$. Worsening of complex coordination test indicators occurred at the account of increasing of time, required for fulfillment of task. Results of complex coordination test characterize general negative changes in the tested psycho-physiological parameters of kinesthetic, responding and orientation qualities of girl students in the process of their study. It should be noted that girl students of all years of study have low level of complex coordination test indicators.

\section{Discussion}

Mental functioning of man is accompanied by changes of functional status of organism's different organs and systems. Value of conditional responses decreases, reaction to different by impact irritators weakens, stability of attention reduces. Sensitivity of visual analyzer increases after insignificant intensive work. Under the greatest load are systems of direct memorizing and concentration of attention. Mental work takes place with weak motor functioning. It results in appearing of conditions of increased fatigue, weakening of workability and worsening of self-feeling.

The conducted by us research expands the data on girl students' psycho-physiological indicators. In contrast to previous researches, conducted by a number of authors [3, 16, 19, and 23] we analyzed rather a wide spectrum of psycho-physiological indicators in dynamic from $1^{\text {st }}$ to $4^{\text {th }}$ years of study in context of heir interconnection with future profession.

Analysis of results of girl students' psycho-physiological indicators showed their ambiguous character from $1^{\text {st }}$ to $3^{\text {rd }}$ years of study. We determined reduction of indicators of movements' amplitude reproduction accuracy, 
pre-set force value, reaction to vertically falling object, indicators of static and dynamic balance. It complies with data of other researchers $[2,4,11,16,22$, and 37].

It should be noted that there is improvement of nervous processes and ability to constructive praxis. The same changes were noted in the works by D.V. Bondarieva [4], V.A. Kyriushin [10], V.I. Martynova [20], L.T. Urumova [25], Zh.L. Kozina [32].

Our research confirms the conclusions of specialists [3, 10, 19, 25, and 38], that uneven reduction of most of psycho-physiological indicators reflects negatively not only in girl students' motor fitness. We proved [12-14], that reduction of these indicators negatively reflects in professional abilities of future teachers.

Influence of physical education in higher educational establishment on development of motor skills and perfection of professionally important psycho-physiological qualities has become extremely important as on to day.

\section{Conclusions}

1. In the research we found reduction of most of indicators of kinesthetic, orientation and responding qualities of girl students in process of study.

2. Purposeful improvement of kinesthetic, orientation and responding qualities with the help of specialized methodic at physical education lessons permits to stop negative dynamic of psycho-physiological indicators and improve them. Finally it will positively reflect in professional skillfulness of pedagogue.

\section{Acknowledgements}

The researches were conducted in compliance with scientific program of physical education faculty of Chernigov national pedagogic university, named after T.G. Shevchenko: "Didactic principles of formation of motor functions of persons, who practice physical education and sports" (state registration number 0108U000854).

\section{Conflict of interests}

The author declares that there is no conflict of interests.

\section{References:}

1. Afanas'eva IV. Metodika sovershenstvovaniia professional'no znachimykh koordinacionnykh sposobnostej u budushchikh specialistov dizajnerov. Cand. Diss. [Methodic of perfection of professionally important coordination abilities of future specialists-designers. Cand. Diss.]: Omsk; 2008. (in Russian)

2. Baribina L, Kozina Zh, Tikhenko V, Tolstobrov A. Testuvannia individual'nikh psikhologichnikh zdibnostej studentiv tekhnichnogo vishchogo navchal'nogo zakladu za dopomogoiu komp'iuternikh tekhnologij [Testing of individual psychological abilities of technical higher educational establishment's students with the help of computer technologies]. V mezhdunarodnaia nauchnaia konferenciia "Problemy i perspektivy razvitiia sportivnykh igr i edinoborstv $v$ vysshikh uchebnykh zavedeniiakh" [5th international scientific conference "Problems and prospects of sports games and martial arts' development in higher educational establishments"], Belgorod-Kharkov; 2009. P. 6-15. (in Ukrainian)

3. Barybina LN, Kozina ZhL. Kharakteristika psikhofiziologicheskikh pokazatelej studentov razlichnykh sportivnykh specializacij [Characteristic of psycho-physiological indicators of students of different sports' specializations]. Physical education of students 2010;4:6-11. (in Russian)

4. Bondarev DV, Gal'chinskij VA. Osobennosti psikhofizicheskikh vozmozhnostej studentov, zanimaiushchikhsia sportivnymi igrami [Specific features of psycho-physical potentials of students' practicing sports games]. Physical education of students 2008;1:59-64. (in Russian)

5. Burlachuk LF. Psikhodiagnostika [Psycho-diagnostic], Sankt Petersburg: Peter; 2006. (in Russian)

6. Gavrilova IN, Gorbunov NP. Sravnitel'naia ocenka psikhofiziologicheskikh pokazatelej studentok, nachinaiushchikh obuchenie $\mathrm{v}$ universitete [Comparative assessment of psycho-physiological indicators of girl students, who start studying at university]. Vestnik Iuzhno-Ural'skogo gosudarstvennogo universiteta 2006; 3(1):189-191. (in Russian)

7. Gorskaia IIu, Suiangulova LA. Bazovye koordinacionnye sposobnosti shkol'nikov s razlichnym urovnem zdorov'ia [Basic coordination abilities of schoolchildren with different level of health] 2000. (in Russian)

8. Dushanin SA. Bal'naia sistema kompleksnogo vrachebno-pedagogicheskogo kontrolia na zaniatiiakh massovymi formami fizicheskoj kul'tury [Points' system of complex medical-pedagogic control at classes of mass forms of physical culture]. Teoriia i praktika fizicheskoj kul'tury 1978;4:49-52. (in Russian) 
9. Kirichenko SI. Professional'no-prikladnaia fizicheskaia podgotovka studentov ekonomicheskogo fakul'teta. Cand. Diss. [Professional-applied physical training of economic faculty students. and. Diss.], Maikop; 1998. (in Russian)

10. Kiriushin VA, Lobanov SP, Stuneeva GI. Dinamika psikhofiziologicheskikh pokazatelej u studentov [Dynamic of students' psycho-physiological indicators]. Gigiena i sanitariia 2003;1:47-49. (in Russian)

11. Kozina ZhL, Delova I, Liashenko A, Kolomiec NA. Kharakteristika psikhofiziologicheskikh pokazatelej u plovcov v lastakh i basketbolistov [Characteristic of psycho-physiological indicators of swimmers in flippers and basketball players]. Physical education of students 2006;6:20-26. (in Russian)

12. Kolumbet OM. Psikhofizichni osoblivosti trudovoi diial'nosti vchiteliv-naochnikiv [Psycho-physical characteristics of work of teachers, using visual aids]. Pedagogics, psychology, medical-biological problems of physical training and sports 2012;8:48-53. (in Ukrainian)

13. Kolumbet OM. Obgruntuvannia specializovanoi fizichnoi pidgotovki vchitelia seredn'oi shkoli [Substantiation of specialized physical training of secondary school teachers]. Pedagogics, psychology, medical-biological problems of physical training and sports 2012;12:59-64. (in Ukrainian)

14. Kolumbet OM. Analiz dinamiki rivnia rozvitku profesijnikh iakostej studentok vishchikh pedagogichnikh navchal'nikh zakladiv [Analysis of dynamic of professional qualities' development of higher educational establishments' girl students]. Molodizhnij naukovij visnik Skhidnoievropejs'kogo nacional'nogo universitetu 2013;9:36-41. (in Ukrainian)

15. Korobejnikov GV. Psikhofiziologicheskie mekhanizmy umstvennoj deiatel'nosti cheloveka [Psychophysiological mechanisms of human mental functioning], Kiev; 2002. (in Russian)

16. Kostyunin AV. Determination of indexes of psychophysiology qualities for the students of universities of different courses that engage in futsal in the process of extracurricular work. Pedagogics, psychology, medical-biological problems of physical training and sports, 2014;7:18-22. doi:10.6084/m9.figshare.1015380

17. Kotova SA. Ispol'zovanie psikhofiziologicheskikh pokazatelej $\mathrm{v}$ ocenke kachestva sovremennogo vuzovskogo obrazovaniia [Determination of psycho-physiological indicators in assessment of quality of modern HEE education]. Psikhologiia obrazovaniia v polikul'turnom prostranstve 2010; 1(1):60-66. (in Russian)

18. Lizogub VS. Individual'ni psikhofiziologichni osoblivosti liudini ta profesijna diial'nist' [Individual psycho-physiological characteristics of man and professional functioning], Fiziologichnij zhurnal 2010;56(1):148-151. (in Ukrainian)

19. Litovchenko OG, Solov'ev VS, Talygina AF. Dinamika psikhofiziologicheskikh pokazatelej studentok pervogo kursa pedagogicheskogo vuza srednego Priob'ia [Dynamic of psycho-physiological indicators of 1st year girl students of middle Priobye pedagogic HEE]. Ekologiia cheloveka 2007;11:52-55. (in Russian)

20. Martynova VI. Dinamika pokazatelej psikhofiziologicheskogo sostoianiia studentok v processe zaniatij po fizicheskoj kul'ture [Dynamic psycho-physiological indicators of girl students in process of physical culture trainings]. Vestnik Baltijskogo federal'nogo universiteta 2006;11:102-106. (in Russian)

21. Leont'ev AN, Gippenrejter IuB. Praktikum po psikhologii [Practicum on psychology], Moscow; 1972. (in Russian)

22. Rovnij AS. Psikhofiziologichne sprijniattia zorovoi informacii rukhovoi diial'nosti liudini [Psychophysiological perception of visual information of human motor functioning]. Pedagogics, psychology, medical-biological problems of physical training and sports 2002;26:17-23. (in Ukrainian)

23. Sidorova KA, Sidorova TA, Dragich OA. Analiz osobennostej psikhofiziologicheskikh pokazatelej organizma studentov v processe ikh obucheniia v VUZe [Analysis of psycho-physiological indicators of students' organism in process of their study at HEE]. Fundamental'nye issledovaniia 2012;5(2):426-430. (in Russian)

24. Trushkova VV. Psikhofiziologicheskie kriterii organizma vo vzaimosviazi s pokazateliami deiatel'nosti nervnoj i serdechno-sosudistoj sistemy [Psycho-physiological criteria of organism in interconnections with indicators of cardio-vascular and nervous systems' functioning]. Uspekhi sovremennogo estestvoznaniia 2005;5:96. (in Russian) 
25. Urumova LT, Botoeva NK, Khetagurova LG. Dinamika psikhofiziologicheskikh pokazatelej u studentovmedikov $\mathrm{v}$ processe obucheniia [Dynamic of psycho-physiological indicators of medical students in process of their studying]. Vestnik novykh medicinskikh tekhnologij 2009;16;3:168-172. (in Russian)

26. Fal'kova OE. Psikhologichni problemi ta krizi v rozvitku osobistosti studenta [Psychological problems and crisis in development of student's personality]. Pedagogics, psychology, medical-biological problems of physical training and sports 2008;7:138-141. (in Ukrainian)

27. Bazylyuk TA. Self-evaluation of health and interests of students of higher education institutions on course physical education. Pedagogics, psychology, medical-biological problems of physical training and sports, 2013;7:3-6. doi:10.6084/m9.figshare.735943

28. Furman YM, Salnikova SV. Improvement of aerobic energy supply processes in 37-49 yrs old women by means of complex aqua-fitness trainings' and methodic of endogenous - hypoxic breathing's application. Pedagogics, psychology, medical-biological problems of physical training and sports, 2015;7:59-63. http://dx.doi.org/10.15561/18189172.2015.0708

29. Hirtz P. Koordinative Fahigkeiten im Schulsport [Coordinative abilities in school sports], Berlin: Volk und Wissen, Volksseigener Verlag; 1985. (in German)

30. Iermakov SS, Apanasenko GL, Bondarenko TV, Prasol SD. Physical culture is a basic instrument of culture of health. Pedagogics, psychology, medical-biological problems of physical training and sports 2010;11:31-33.

31. Iermakov SS, Ivashchenko PI, Guzov VV. Features of motivation of students to application of individual programs of physical self-preparation. Physical Education of Students 2012;4:59-61.

32. Kozina ZL, Iermakov SS. Analysis of students' nervous system's typological properties, in aspect of response to extreme situation, with the help of multi-dimensional analysis. Physical Education of Students, 2015;3:10-19. http://dx.doi.org/10.15561/20755279.2015.0302

33. Korobeynikov G. Psychophysiological Peculiarities of Sexual Dimorphism in Athletes. Psychologe Research 2012;2(6):336-342.

34. Loewenstein V.R. Handbook of Sensor. Physiology. Principles of Receptor Physiology. BerlinHeidelberg-New York: Springer; 1992.

35. Masliak I.P., Physical health of young and middle age women under influence of step-aerobics exercises. Pedagogics, psychology, medical-biological problems of physical training and sports, 2015;10:45-50. http://dx.doi.org/10.15561/18189172.2015.1007

36. Pogrebniak IM, Kudelko VE, Nagovitsina OP. Effect of improving aerobics classes at the level of flexibility of female students. Pedagogics, psychology, medical-biological problems of physical training and sports, 2013;5:49-52. doi:10.6084/m9.figshare.707099

37. Pop C, Ciomag V. The Influence of Aerobic Gymnastics on the Students' Body Image. Procedia - Social and Behavioral Sciences 2014;117:129-135.

38. Prusik Krzysztof, Prusik Katarzyna, Kozina ZhL, Iermakov SS. Features of physical development, physical preparedness and functional state of boys and girls - students of Polish higher educational establishments. Physical Education of Students 2013;1:54-61. doi:10.6084/m9.figshare.96415

39. Tunnemann H. Evolution and adjustments for the new rules in wrestling. Psychophysiological International Journal of Wrestling Science 2013;3(2):94-105. 


\section{Information about the author:}

Kolumbet A.N.; http://orcid.org/0000-0001-8775-4232;

re_play@3g.ua; Kiev National University of Technology and Design; st. Nemirovich-Danchenko, 2, Kiev, 14013, Ukraine.

Cite this article as: Kolumbet A.N. Dynamic of girl students' psycho-physiological indicators in process of their study at pedagogical higher educational establishment. Physical education of students, 2016;1:29-36. doi:10.15561/20755279.2016.0104

The electronic version of this article is the complete one and can be found online at: http://www.sportpedu.org.ua/html/arhive-e.html

This is an Open Access article distributed under the terms of the Creative Commons Attribution License, which permits unrestricted use, distribution, and reproduction in any medium, provided the original work is properly cited (http://creativecommons.org/licenses/by/4.0/deed.en).

Received: 03.01.2016

Accepted: 12.01.2016; Published: 25.02.2016 